\title{
Extensive Reading with Authentic Materials
}

\section{Andrew Blaker}

Konan University

Timothy H. Ellsworth

Konan University

\section{Reference Data}

Blaker, A., \& Ellsworth, T. H. (2021). Extensive reading with authentic materials. In P. Clements, R. Derrah, \& P. Ferguson (Eds.), Communities of teachers \& learners. JALT. https://doi.org/10.37546/ JALTPCP2020-41

This paper describes an action research project on modifying an extensive reading (ER) program by replacing graded readers with authentic materials in its final semester. This was done in response to low student engagement with ER in previous semesters. Twenty-one second year university students were introduced to authentic materials via the instructor, then shown how to self-select for level-appropriate materials of interest. The paper details the environment in which this occurred. Student feedback responses suggest that the assignment improved student engagement and ultimately provided a meaningful learning experience.

本論は、グレーデッドリーダーを正規の教材の代替として利用する多読(ER) プログラムの導入に関するアクションリサーチ プロジェクトについて説明する。これは、前学期に学生のERへの関与が少なかったことに対応して行われたものである。大学 2年生 21 人を対象に、インストラクターを通じて正規の教材が紹介され、次にレベルに適した興味のある教材を自己選択する 方法が示された。学生からのフィードバックによると、当該課題は学生の関与を改善し、最終的に有意義な学習体験を提供し たことを示唆している。

xtensive reading (ER) has become an important part of university English courses in Japan and provides many benefits to students. However, in practice, alongside students' busy course loads, it can be difficult for students to maintain motivation to read the volumes required by ER programs. This paper describes just such a situation in a Japanese university setting and presents one alternative solution to allow students more freedom in choosing their own authentic English reading materials, in order to overcome issues of student motivation while attempting to meet ER program requirements. This is carried out as an action research project, to gauge the impact on the motivation of the students to continue reading not only through their third semester, but also with the goal that they develop reading skills and habits for use in their future.

\section{Overview of Extensive Reading}

"Students learn to read by reading a lot" (Grabe \& Stoller, 2002, p. 90), meaning students must increase their input to improve reading skills. ER is a type of reading instruction with the purpose of gaining a general understanding by reading a large volume of material. ER has been shown to have a positive impact on vocabulary acquisition (Nation \& Wang, 1999), reading habits (Bamford \& Day, 2002), motivation (Takase, 2003), and reading rate (Taguchi et al., 2004). Ten core principles of ER described by Bamford and Day (1997) are outlined as follows:

1. Students read as much as possible, perhaps in and definitely out of the classroom.

2. A variety of materials on a wide range of topics is available so as to encourage reading for different reasons and in different ways.

3. Students select what they want to read and have the freedom to stop reading material that fails to interest them.

4. The purposes of reading are usually related to pleasure, information and general understanding. These purposes are determined by the nature of the material and the interests of the student.

5. Reading is its own reward. There are few or no follow-up exercises to be completed after reading. 
6. Reading materials are well within the linguistic competence of the students in terms of vocabulary and grammar. Dictionaries are rarely used while reading because the constant stopping to look up words makes fluent reading difficult.

7. Reading is individual and silent, at the student's own pace, and, outside class, done when and where the student chooses.

8. Reading speed is usually faster rather than slower as students read books and other material that they find easily understandable.

9. Teachers orient students to the goals of the program, explain the methodology, keep track of what each student reads, and guide students in getting the most out of the program.

10. The teacher is a role model of a reader for students--an active member of the classroom reading community, demonstrating what it means to be a reader and the rewards of being a reader.

ER has gained popularity in Japan in recent decades (Takase, 2010), with ER in university English programs becoming common practice from the early 2000s (Nishizawa et al., 2010). This has in part been as a response to the largely intensive reading experience of Japanese students during secondary education (Conway, 2012). A cumulative goal of one million words over the course of a four-year university program was put forward as a goal for Japanese learners of English (Sakai, 2002). However, the outcome of ER is not simply the consumption of large quantities of material, but also that students enjoy the reading (Day, 2004) and develop intrinsic motivation to read (Krashen, 2004). This is to encourage them to continue reading after course completion. If students have a positive reading experience, the likelihood of them continuing to read for personal reasons beyond the scope of the course increases (Bandura, 1997).

ER can be done in several ways, but one common method is to use graded readers. These are an excellent resource for unlocking the benefits of ER because they offer students simplified access to a wide variety of fiction and non-fiction genres and can serve as stepping-stones towards reading unsimplified texts (Waring, 2003). The graded aspect of the readers refers to the book's level, which is determined by factors such as its length, and grammatical and lexical complexity (Prtljaga et al., 2015). The number of levels varies depending on the publisher, but it is generally agreed on that the higher the level, the closer the book is to an unsimplified text. The ideal situation would be for students to advance through graded reader levels and then make a smooth transition to reading authentic texts. However, given time constraints, student level, and especially motivation, this cannot always be achieved.

\section{Our Situation}

Both authors teach in the study abroad program of a mid-sized private university in Western Japan. The program runs over three semesters and has on average 24 students. Students are initially divided into two classes by their scores on the Global Test of English Communication (GTEC) and later by their TOEFL scores and class grades. The primary goal of the study abroad program is to prepare students to take classes at affiliate schools in either the United States, Canada, or the United Kingdom. Over the course of three semesters, students take classes that are designed to develop their proficiency in each of the four skills (reading, writing, speaking, and listening), and increase their scores on standardized tests like TOEFL and the International English Language Testing System (IELTS). Students begin the program with a TOEFL internet-based test (iBT) score of between 30-50 and have achieved a score of between $40-70$ by the time they begin this reading course. When students reach a threshold score, they can study at an affiliate university overseas, ideally in mainstream English-medium classes; however, slightly lower scores qualify them to take advanced English Language classes until they are ready to enter the mainstream classes.

The program has three academic reading classes, each with an ER component. Initially, ER was managed exclusively through the M-Reader website, which is commonly used in ER programs as it contains thousands of quizzes for graded readers. When a student finishes a graded reader, they log into the site, take a corresponding comprehension quiz, and upon passing are awarded the word count of the book as points. Teachers set a target word count goal for the semester and each successfully passed test moves the student closer to this goal. For the three semesters of the study abroad program, students are assigned targets of 100,000, 120,000, and 150,000 words respectively. Students do most of their ER as homework; however, class time is devoted to silent sustained reading (SSR) and follow-up sessions where students discuss what they are reading in small groups.

\section{The Problem}

This section provides a brief overview of the semester-to-semester flow of the ER cycle. This summary is a composite of personal observations by the authors, anecdotal evidence from previous instructors, and when noted, the details of brief informal surveys, or one minute papers (OMP) (Chizmar \& Ostrosky, 1998; Stead, 2005) distributed by the 
authors at the end of class. These were administered during the middle of the semester and served as an informal evaluation of the course by the students. All OMPs were anonymous, and the students could submit in either English or Japanese.

Because the program spans three semesters, the authors had the opportunity to teach both the first and final reading classes of the program during the spring semester. Both authors noticed a stark difference in the students' attitudes towards ER. First-year students taking the initial Academic Reading class were quite engaged in ER. Post-SSR conversations were lively and generally on topic. Student feedback from the OMPs suggested that the students were excited to read a high volume of books in English, and many of them expressed an interest in reading stories as a counterbalance to the more topical, factual material of their textbooks. The authors observed that most of the students in their classes either achieved or exceeded the word-count target, and those who did not come close.

The attitudes of students in their third semester were quite different. One possible reason for this was that most students knew whether or not they would study abroad. Discussions with other instructors in the program who had previously taught the reading courses revealed that because many students had likely reached the threshold score necessary to enter a program at the university of their choice, they may have made an attitudinal shift towards preparing to study overseas. For these students, SSR and ER in general was no longer of interest or perceived value. Other students, including those who had not hit their threshold score, reported in OMPs and personal conversations that they were tired of reading graded readers and felt that they did not help them prepare for the TOEFL. Some expressed the view that time would be better spent reading authentic materials similar to what they would encounter overseas or on the TOEFL. By the end of the semester, SSR was rarely done and very few of the students completed the ER component of the course.

After the lackluster performance of the previous cohort in the second semester, the authors decided to monitor the ER component closely during the students' second semester. Towards the end of this third semester, many students were trying to hit the goal simply to complete the assignment. It was frequently observed that during post-SSR discussions, students asked each other about word counts and whether or not the test for a given book was easy, rather than discussing their impressions of the book's contents. By the end of the semester, students were obviously not as engaged in ER, and few hit the 120,000-word target. While this is likely related to the extra emphasis given in the second semester to the TOEFL both in and out of class, it was clear that students put less priority on ER. Fearing another third semester like the one previously mentioned, the authors decided to make a change to the ER system during students' third semester.

\section{Solution + Rationale}

The decision was made to stop using M-Reader during the third semester and instead allow the students to read about topics of interest to them using authentic materials. For the purposes of this article, Morrow's (1977) definition of authentic materials as those containing "real language, produced by a real speaker or writer for a real audience and designed to convey a real message" (p. 13) will be used. During the first two weeks of class, students were asked to choose a topic of interest to them that they would read about for half a semester.

The rationale for change came from a desire to rekindle the students' passion for reading by allowing them to develop a deeper level of knowledge about a topic they were already interested in. Over the course of three semesters, the teachers got to know quite well, through writings, presentations, and daily conversations, what the students were passionate about; however, much of this was not covered in their intensive reading materials nor any of the graded readers. It was anticipated that by shifting from an extrinsic form of motivation (i.e. M-Reader scores) to a more intrinsic motivation (i.e. learning more about topics students want to discuss with others in English whilst studying abroad) that students might continue to maintain interest in reading outside of class.

The decision to use authentic materials is supported by a large body of research. One of the most reported benefits is the increase in student motivation to learn and use the target language (Berardo, 2006; Guo, 2012; Kelly et al., 2002; Thomas, 2014; Peacock, 1997). This motivation can take the form of interest in the topics being presented, interest in the materials themselves, and even the amount of time spent on-task during class (Crookes \& Schmidt, 1991). Likewise, showing students that they can cope with authentic materials can lead to an increase in intrinsic motivation and therefore increase the likelihood that they will complete the assignments (Bandura, 1997).

Students are also encouraged to read authentic texts to avoid relying solely on materials designed for language learners (Aebersold \& Field, 1997), and this exposure to "real" language, as well as authentic cultural input, can help ground students in the background knowledge necessary for using the language correctly (Berardo, 2006). Also, authentic materials are readily available and versatile, making them very useful for teachers to find and adapt for their classes, and for students to match with their needs and interests (Gilmore, 2007).

The biggest criticism against the use of authentic materials is that they are too difficult for the students to comprehend. However, this issue is dealt with if the 
instructor provides the students with accompanying tasks that are designed to help them understand the materials (Rogers \& Medley Jr., 1988). Baleghizadeh (2010) conducted an experimental study on the effects of using simplified, negotiated, and unmodified texts on Iranian EFL students' reading comprehension. The study found that students who were able to negotiate the meaning of an authentic text through communicating with their teacher showed greater comprehension than those who read simplified versions of the same text. Also, Guariento and Morley (2001) found that authentic materials can be introduced easily at the post-intermediate level but need some modification for lower learners. They concluded that if students are developing effective compensatory strategies for extracting meaning from these difficult texts, total understanding is not deemed necessary -- the task itself is authentic in this way. Furthermore, Guariento and Morley (2001) found that using authentic texts can serve as a bridge between what students can do and their potential to engage in real world events.

While there is a paucity of literature on the use of authentic materials and ER, Guo (2012) found that assigning authentic materials as supplementary ER materials for what students were reading about in class led to significant gains in vocabulary and motivation to study. While just one study, it underscored the need to explore the option of incorporating authentic materials into an ER program. Considering this, the authors developed a set of assignments to bring authentic materials as ER resources into the third semester of the study abroad program.

\section{Meeting ER Program Requirements}

While one primary concern was keeping students motivated and reading, it was essential that any replacement of the previous ER system was still valid, meeting at least the basic requirements of an ER program. This section uses Bamford and Day's (1997) list of ten core ER principles to consider the validity of this replacement, and the decisions that were made to address any issues.

In reviewing these principles, it was determined that conditions were met, but that points six and nine were possibly of concern. Of initial concern was number six, Readings are within the linguistic competence of students. As reading is primarily done outside of the classroom, it is impossible for the teacher to monitor the bulk of the content the students are reading. In response, it was decided to incorporate training to allow students to adequately self-select level-appropriate materials. As part of their Academic Reading courses, students are taught how to deal with unknown words; however, to ensure simpler materials were selected, in-class activities in which students were shown materials of a range of difficulties and a simple method of gauging appropriateness was taught. The Five Finger Rule (Hudson \& Williams, 2015) is a method in which as students read, each time they encounter a word they do not know they lift a finger on one hand. If the five fingers on one hand are lifted after one page, it is considered too difficult. Using a method as simple as this, students become more aware of what is appropriate for them.

The next concern was point nine, Teachers orient students. Again, as students read outside of class, it was important the teachers continued to offer guidance. The reading $\log$ is a method for bringing the reading homework into the classroom. Students can discuss their topics with classmates and share vocabulary and ideas. Teachers can engage in these student discussions and offer further questions or suggestions. The reading $\log$ also contains a section for students to ask questions of their teacher (informed by the findings of Baleghizadeh, [2010]), or discuss the topic using the language and ideas they have learned. This section of the reading log is a place for the teacher to offer more private or detailed guidance for the week ahead.

By offering students guidance on self-selecting materials and providing an oral and written forum for engaging with the teacher about the content being read, these predicted issues were overcome.

\section{Student Activities}

The students have two main activities to perform for the ER project. First is the weekly reading $\log$, and the second is a final presentation of what they have learned. The reading $\log$ is the weekly output the students must complete. The appendix is a copy of the incomplete reading log, and Table 1 shows each section to be completed, and the purpose it holds for the teacher and student.

The reading log was submitted weekly, and time was provided in class for students to share the contents of their reading. During this time the teacher discussed topics and provided feedback or questions to help students develop ideas further.

Students were then asked to give a presentation on their topic explaining ideas they had learned, showing how their reading topic developed over time, and introducing both general and technical vocabulary learned in their reading. Presentation format was relatively free, but an example presentation was given by the teachers as a demonstration of the idea. The first presentation was scheduled for the middle of the semester, and thereafter students were given the opportunity to either change their topic, or to continue learning about the same topic until the end of the semester. 
JALT2020

COMMUNITIES OF
TEACHERS \& LEARNERS

Table 1

Reading Log Components

\begin{tabular}{|c|c|}
\hline Section & Purpose \\
\hline Title & The title(s) of what was read \\
\hline Source & $\begin{array}{l}\text { A full URL of the online content read so the teacher can } \\
\text { review it }\end{array}$ \\
\hline Summary & $\begin{array}{l}\text { This provides a summary for the teacher and allows the } \\
\text { student to reflect on what has been read, expressing it in their } \\
\text { own words. }\end{array}$ \\
\hline $\begin{array}{l}\text { What did you find } \\
\text { most interesting? }\end{array}$ & $\begin{array}{l}\text { This allows students to consider what it is they like about the } \\
\text { topic. }\end{array}$ \\
\hline New words or phrases & $\begin{array}{l}\text { This key section encourages students to record vocabulary, } \\
\text { jargon, phrases, and even slang related to their topic. This } \\
\text { encourages students to immerse themselves in the topic. }\end{array}$ \\
\hline $\begin{array}{l}\text { How does it connect } \\
\text { to your main topic? }\end{array}$ & $\begin{array}{l}\text { Students are encouraged to venture deeply into their topic, } \\
\text { even branching out into related topics. This is a chance for the } \\
\text { students to show how these topics are connected. }\end{array}$ \\
\hline $\begin{array}{l}\text { Questions/Comments } \\
\text { for the teacher }\end{array}$ & $\begin{array}{l}\text { This provides the opportunity for the students to clarify } \\
\text { meaning, seek guidance from the teacher, or even engage in } \\
\text { discussion with the teacher about the topic. }\end{array}$ \\
\hline
\end{tabular}

\section{Issues}

This section introduces post-facto concerns about the implementation of the ER program. Three primary issues were reading volumes, issues regarding student attitudes toward the presentation, and how having the presentation affected student understanding of the ER process.

The first issue encountered was the concern that under the previous semesters' monitored ER program, students met weekly word counts which could be verified through reading completion quizzes. Under this new system, students were expected to continue reading for the same length of time as previously, but without the monitoring provided by those tests. While reading length can be quantified by judging the number of words from each page, it was decided not to use this metric to measure progress. The goal of this project was to have students develop expertise in their topics, and finding and using language to introduce and discuss the content. If students were reading sufficient quantities to make progress in their task, it was decided not to impose word minimums. The benchmark was that they learn something, rather than meet a set number of words.

The next issue was that some students decided to change their topic because they felt uncomfortable presenting it to their peers. More specifically, they felt that the topic would make their classmates uncomfortable and therefore switched to something they perceived as lighter or more entertaining. The purpose of this assignment was for students to read extensively on a topic of interest, and therefore these incidents of what the authors believed to be self-censorship run counter to that purpose. While the number of times students reportedly changed topics for this reason was minimal, it raises the question of whether or not the presentation component of the assignment is necessary.

The final issue encountered was the effect of having a final presentation on student expectations. At the end of each ER project, students gave a presentation introducing what they had learned. This gave some students the impression that they were conducting a research assignment, causing them to engage in intensive, rather than extensive reading. This is the opposite of the intended effect, and serious consideration should be given to either removing the presentation, changing the nature of the presentation, or modelling the presentation in such a way for the students that makes clear the goal is to understand the topic broadly, rather than reading for detailed understanding.

\section{Responses to Implementation}

Preliminary responses from both students and teachers involved have been overwhelmingly positive. Feedback from both OMPs and from the end of course evaluations revealed that many students enjoyed reading about topics they were interested in and learning about the topics their friends and classmates chose. Moreover, while the students were not prompted to compare the new assignment to the previous form of ER, several students felt compelled to write that they preferred reading authentic materials to the managed graded reader system. This is possibly a result of the novelty of the new assignment, but it is worth noting that many students mentioned that reading the authentic materials gave them a sense of accomplishment and that they now felt more confident to read online sources in English.

Accordingly, the teachers involved felt the assignment was a success. Initially, the topics the students chose were predictable as they matched what we knew the students 
were interested in; however, it was enjoyable to read their logs and see them learn more about what they liked. The topics the students chose for the second round were also very interesting to read about. Despite some of the issues with the presentation assignment, the students managed to synthesize their readings into interesting, coherent, and enjoyable output.

\section{Conclusion}

As ER programs become more ubiquitous in Japanese universities, this issue becomes more prevalent. This paper offers possible alternatives for those looking to overcome motivational issues or require an option for using authentic materials in the classroom.

The implementation of this ER program in students' third semester met the requirements of an ER program, and yielded positive attitudes, but further research is required to ascertain the impact of the change. Testing of students' vocabulary levels and comparing these to both previous years and to the progress of their peers in other programs would provide a useful benchmark. Future research regarding students' reading habits after leaving the program would also prove enlightening, as would developing research around the development of autonomous learning in students who engage in this ER program.

This action research project has been an attempt to overcome issues in student motivation in the final of three semesters of ER. While there have been issues found with its implementation, the fundamental goal of the project has been achieved: to provide skills and confidence for students to engage with English in an authentic way, and to encourage reading even after they are no longer required to read English by their university courses.

\section{Bio Data}

Andrew Blaker comes from New Zealand and has been teaching in Japan for 11 years. His research interests are vocabulary acquisition, authentic materials, and testing. $<$ a blaker@konan-u.ac.jp>

Timothy H. Ellsworth has taught English in both Second and Foreign language contexts for the last 11 years. His research interests include the use of authentic materials, differentiated instruction, and extensive listening. <tells@konan-u.ac.jp>

\section{References}

Aebersold, J. A., \& Field, M. L. (1997). Vocabulary issues in teaching reading. From reader to reading teacher: Issues and strategies for second language classrooms. Cambridge University Press.

Bamford, J., \& Day, R. (1997). Extensive reading: What is it? Why bother? Language Teacher-KyotoJALT, 21, 6-8.

Bamford, J., \& Day, R. (2002). Top ten principles for teaching extensive reading. Reading in a Foreign Language, 14(2), 136-141.

Bamford, J., \& Day, R. R. (2004). Extensive reading activities for language teaching. Cambridge University Press.

Berardo, S. A. (2006). The use of authentic materials in the teaching of reading. The Reading Matrix, 6(2)

Baleghizadeh, S. (2010). The impact of student-initiated interaction on EFL reading comprehension. Studies in Literature and Language, 1(4), 20-28.

Bandura, A. (1997). Theoretical perspectives. Self-efficacy: The exercise of control, 1-35. W H Freeman \& Co.

Chizmar, J. F., \& Ostrosky, A. L. (1998). The one-minute paper: Some empirical findings. The Journal of Economic Education, 29(1), 3-10.

Conway, N. (2012). Notes on extensive reading: Japanese university classes and graded readers. Journal of Bunkyo Gakuin University Department of Foreign Languages 12, 229-239.

Crookes, G., \& Schmidt, R. W. (1991). Motivation: Reopening the research agenda. Language Learning, 41(4), 469-512.

Day, R. (2004). A critical look at authentic materials. Journal of AsiaTEFL. 1(1), 101-114.

Gilmore, A. (2007). Authentic materials and authenticity in foreign language learning. Language Teaching, 40(2), 97-199.

Grabe, W., \& Stoller, F. (2002). Teaching and research reading. Longman.

Guariento, W., \& Morley, J. (2001). Text and task authenticity in the EFL classroom. ELT Journal, $55(4), 347-353$.

Guo, S. C. (2012). Using authentic materials for extensive reading to promote English proficiency. English Language Teaching, 5(8), 196-206.

Hudson, A. K., \& Williams, J. A. (2015). Reading every single day: A journey to authentic reading. The Reading Teacher, 68(7), 530-538.

Kelly, C., Kelly, L., Offner, M, \& Vorland, B. (2002). Effective ways to use authentic materials with ESL/EFL students. The Internet TESL Journal. Retrieved from http://iteslj.org/Techniques/KellyAuthentic.html

Krashen, S. D. (2004). The power of reading: Insights from the research. ABC-CLIO. 


\section{JALT2020}

COMMUNITIES OF
TEACHERS \& IEARNERS

Morrow, K. (1977). Authentic texts in English for specific purposes. Modern English Publications.

Nation, P., \& Wang Ming-tzu, K. (1999). Graded readers and vocabulary. Reading in a Foreign Language, 12(2), 355-379.

Nishizawa, H., Yoshioka, T., \& Fukada, M. (2010). The impact of a 4-year extensive reading program. In JALT2009 Conference Proceedings, 632-640. Retrieved from https://jalt-publications. org/archive/proceedings/2009/E035.pdf

Peacock, M. (1997). The effect of authentic materials on the motivation of EFL learners. ELT Journal, 51(2), 144-156.

Prtljaga, J., Palinkašević, R., \& Brkić, J. (2015). Choosing the adequate level of graded readers Preliminary study. Research in Pedagogy, 5(2), 1-16.

Rogers, C. V., \& Medley Jr., F. W. (1988). Language with a purpose: Using authentic materials in the foreign language classroom. Foreign Language Annals, 21(5), 467-478.

Sakai, K. (2002). 快読100万語[Toward one million words and beyond]. Chikuma Shobo.

Stead, D. R. (2005). A review of the one-minute paper. Active learning in higher education, 6(2),

118-131. Taguchi, E., Takayasu-Maass, M., \& Gorsuch, G. J. (2004). Developing reading fluency in

EFL: How assisted repeated reading and extensive reading affect fluency development. Reading in a foreign language, 16(2), 70-96.

Takase, A. (2003). The effects of extensive reading on the motivation of Japanese high school students (Doctoral dissertation, Temple University).

Takase, A. (2010). 英語多読多聴指導 [Teaching manual for extensive reading and listening]. Taishukan

Thomas, C. (2014). Meeting EFL learners halfway by using locally relevant authentic materials. In English Teaching Forum 52(3), 14-23). US Department of State.

Waring, R. (2003). Writing a graded reader. Extensive Reading Central. Retrieved from https://www. er-central.com/authors/writing-a-graded-reader/writing-graded-readers-rob-waring/

\section{Student Reading Log}

\section{Appendix}

The purpose of this Reading Log is for you to read in English about a topic that you are interested in. Rather than focusing on reading graded readers, you are encouraged to read articles from authentic sources. These can be blogs, newspapers, websites (homepages, Wikipedia, reddit, etc.), books, etc. The ultimate goal is for you to read a number of articles about a topic you are interested in and have short discussions about them in class.

As for choosing a topic, you can read about a general topic you are interested in (business, music, fashion, food, travel, etc.) or you can follow a particular story in the news or focus on something that you want more information on. Remember, you will give a short presentation on this topic or story, so you want to be able to explain.

Where can I find some materials? For news stories, try Asahi Weekly, The Mainichi Weekly, The Japan Times ST, The Japan Times (these can all be found in the Ozone or on-line), Asahi Shimbun , Japan Today, The Japan Daily Press, CNN (On Japan), BBC (Japan).

Please use the following template to complete this weekly assignment.

\section{Title of article: \\ 2. Source:}

3. Summary - what is this article about?

6. Questions for the teacher: 